\title{
乾燥収縮迅速評価システムの開発
}

\author{
百瀬晴基*1・閑田徹志*2・今本啓一 $*^{* 3}$ 。橋博三*4
}

\begin{abstract}
概 要 5 週間の短期間で長期のコンクリートの乾燥収縮ひずみを判定する乾燥収縮迅速評価システムを開発し，多く の実工事に関連するレディーミクストコンクリートに適用した。本システムの開発にあたり, 省力化の実現が可能な乾燥 収縮の試験力法之して省力化乾燥収縮試験法を提案するとともに，長期の乾燥収縮ひずみを短期デー夕から予测する予测 手法として外挿法を提案した。本システムを, 実工事に関連する 280 調合のレディーミクストコンクリートに適用すると ともに，長期の乾燥収縮ひずみを短期間の測定データから高い精度で判定できることを確認した。 キーワード：乾燥収縮, 乾燥収縮試験法, 予測, 短期データ, レディーミクストコンクリート
\end{abstract}

1.はじめに

$\mathrm{RC}$ 造構造物では, 而久性および美観上の理由から， コンクリートのひび割れに対する関心は極めて高い。特 に壁や床など面部材が多い建築構造物では，乾燥収縮に 起因するひび割机が問題となっており，ひび割れを抑制 する技術や制御する技術が強く望まれている。

このひび割れを制御する上で，コンクリートの乾燥収 縮ひずみ定量的に評価することは極めて重要であり, 09 年 2 月に改正された JASS 5 では, 計画供用期間の 級が長期または超長期の場合に，レディーミクストコン クリートの乾燥収縮ひずみを施工前に把握することを義 務づけている”。コンクリートの乾燥収縮ひずみを評価 する指標として, 例えば JIS A 6204 では, 乾燥開始材 齢を 7 日とし， $20 \pm 3^{\circ} \mathrm{C}, \mathrm{RH} 60 \pm 5 \%$ の環境下で気乾養 生とした乾燥期間 6 力月の長さ变化率を用いており, 测 定方法はJIS A 1129 による方法を採用している。この 指標はコンクリートの乾燥収縮ひずみを評価する指標之 して, 通常良く用いられており, 日本建築学会の鉄筋コ ンクリート造建築物の収縮ひび割れ制御設計・施工指針 (案) ・同解説においても採用されている2)。今後コンク リートの乾燥収縮ひずみに関する品質評価や品質管理上 して, JIS A 1129 による長さ変化試験が多く実施され ることが予想される。

近年では，レディーミクストコンクリート工場におい て乾燥収縮ひずみに関するデータが蓄積されつつある が3), 全ての工場においてデータが整備されていないの が実情である。その結果, 実工事において, 打設前に使 用するレディーミクストコンクリートの乾燥収縮ひずみ の品質評体を行うことが予想される。この品質評価には,

*1 ももせ・はるき/鹿島建設鿟技術研究所 研究員 (正会員)

*2 かんだ・てつし/鹿島建設條技術研究所上席研究員 (正会員)

*3 いまもと・けいいち/東京理科大学 工学部 第二部 建築学科 准教授 (正会員)

*4 みはし・ひろぞう/東北大学大学院工学研究科都市・建筑 学専攻 教授（正会員）
JIS A 1129 による長さ変化試験を行うことが望ましい が, 最低 6 力月の試験期間が必要であり, 評価結果を実 際の工事に反映させることは困難な状況にある。また, この JIS A 1129 による長さ変化試験は, 工場では一般 的とは言い難い $100 \times 100 \times 400 \mathrm{~mm}$ の角柱供試体を使 用し, 長さ变化の测定にも習熟が必要であることから, 大きな労力を要する試験であるといえる。

以上の背景に鑑み，筆者らは，試験体作製から 5 週間 の短期間で長期の乾燥収縮ひずみを判定する乾燥収縮迅 速評価システムを提案した。本論では, 乾燥収縮迅速評 価システムを紹介するとともに，本システムを 79 物件, 計 280 調合のコンクリートに適用した事例について報告 する。

\section{2. 乾燥収縮迅速評価システムの概要}

乾燥収縮迅速評侕システムの概要を図-1 に示す。コ ンクリートの乾燥収縮における材料特性值は, JIS A 1129 (以下, JIS 法と称する) により測定した乾燥材噛 182 日における值として評価することができる22。一方, 乾燥収縮迅速評価システムでは, 省力化乾燥収縮試験法 により 28 日間の乾燥収縮ひずみを测定し，外挿法によ り JIS 法の乾燥材龄 182 日の乾燥収縮ひずみを予測す ることで，短期間に乾燥収縮の材料特性值を評価できる。 すなわち, 本システムは, 試験精度を損なうことなく省 力化を実現する『省力化乾懆収縮試験法』と, 4 週間の 乾燥収縮ひずみデー夕から乾燥材齢 182 日の乾燥収縮ひ ずみ予測できる『外挿法』から構成される技術である。 なお，本システムは，2007年1月に(狽日本建築総合試 験所の性能証明（第 06-19 号）を取得している。

\section{3. 省力化乾燥収縮試験法}

\section{1 省力化乾燥収縮試験法の概要}

乾燥収縮試験方法の概要を表-1 に示す。JIS 法は, コンクリートの実務においては用いることの少ない 100 $\times 100 \times 400 \mathrm{~mm}$ の角柱供試体老用いており，長さ变化 


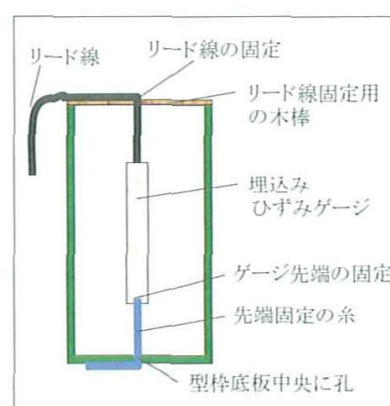

少力化法詳細図 $(\phi 100 \times 200 \mathrm{~mm})$

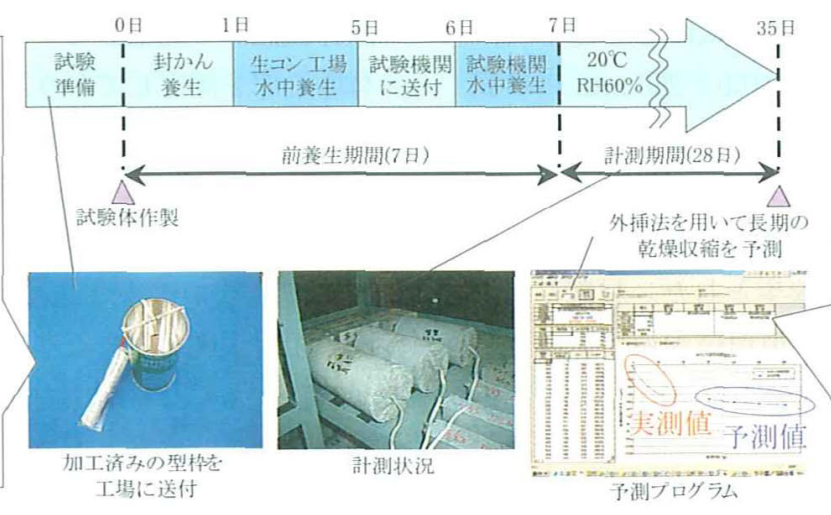

図-1＼cjkstart乾燥収縮迅速評価システムの概要

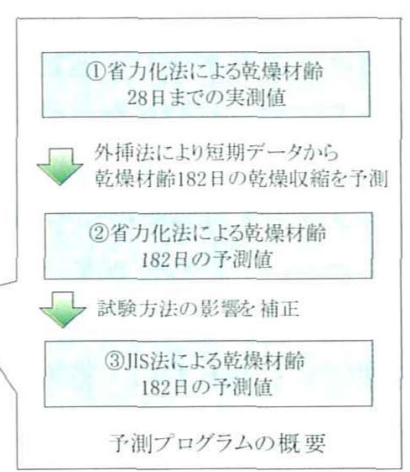

予測ブログラムの斟要
表-1 試験方法の概要

\begin{tabular}{|c|c|c|}
\hline 試騃方法 & 自力化法 & JIS 法 (JIS A 1129-1) \\
\hline 供試体形状 & Ф $100 \times 200 \mathrm{~mm}$ & $100 \times 100 \times 400 \mathrm{~mm}$ \\
\hline 型染 & 軽量型枠 & 銅製型枠 \\
\hline 測定方法 & 埋込みひずみゲージ & コンパレータ法 \\
\hline
\end{tabular}

の測定は測定者の手作業によるため, 多数の乾燥収縮試 験を実施するには大きな労力が必要之なる。

これに対して，筆者らが提案した省力化乾燥収縮試験 法（以下，省力化法之称する）は，図-1に示す位置に 埋込みひずみゲージを埋設した $\Phi 100 \times 200 \mathrm{~mm}$ の円柱 供試体を用いており，長さ変化の測定は静ひずみ測定器 による自動計測により実施する゙。省力化法で用いる埋 込みひずみゲージは，ひずみゲージの被覆樹脂表面に凹 凸処理が施されて戈り，この被覆樹脂のヤング係数がコ ンクリートの $1 / 10$ 程度 $\left(2750 \mathrm{~N} / \mathrm{mm}^{2}\right)$ と比較的小さ いことからコンクリートの体積变化に対する追従性が良 いことを特徵としている。すなわち，埋込みひずみゲー ジをセットした使い捨ての軽量型杂を工場に送付し試験 体を作製することで, 試験体作製時の労力を削減し，長 さ変化の測定を自動計測により実施することで測定時の 省力化を図っている。

\section{2 検 討 概 要}

省力化法と JIS 法の試験方法の差が，乾燥収縮試験 の測定結果に与える影響を検討するべく，表-2に示す 計 14 調合について, 省力化法抢よび JIS 法に上る乾燥
表-2 省力化法の検討に供した調合の一覧

\begin{tabular}{|c|c|c|c|c|c|c|c|}
\hline $\mathrm{NO}$ & 配合 & $\begin{array}{c}W \\
\left(\mathrm{~kg} / \mathrm{m}^{3}\right)\end{array}$ & $\begin{array}{l}W / C \\
(\%)\end{array} \mid$ & $\begin{array}{l}s / a \\
(\%)\end{array}$ & 粗骨材 & 細骨材 & $\begin{array}{l}\text { 混和凧 } \\
\text { 種類* }\end{array}$ \\
\hline 1 & 普通-27-18-20-N & 183 & 53.0 & 45.7 & 石灰岩 & 陸砂 & $\mathrm{AE}$ \\
\hline 2 & 苝通-30-18-20-N & 184 & 50.0 & 45.0 & 石灰岩 & 陸砂 & $\mathrm{AE}$ \\
\hline 3 & 普通-33-18-20-N & 170 & 48.0 & 45.6 & 石灰岩 & 陸砂 & 高 $\mathrm{AE}$ \\
\hline 4 & 揞通-27-18-20-N & 180 & 54.5 & 46.4 & 砂岩 & $\begin{array}{l}\text { 陸眇 } 70 \% \\
\text { 石灰岩 } 30 \%\end{array}$ & $\mathrm{AE}$ \\
\hline 5 & 普通-30-18-20-N & 184 & 50.0 & 45.1 & 砂岩 & $\begin{array}{l}\text { 陸砂 } 70 \% \\
\text { 石灰岩 30\% }\end{array}$ & $\mathrm{AE}$ \\
\hline 6 & 普通-33-18-20-N & 170 & 48.5 & 46.7 & 砂岩 & $\begin{array}{c}\text { 陸酹 } 70 \% \\
\text { 不灰岩 } 30 \%\end{array}$ & 高 AE \\
\hline 7 & 普通-24-15-20-N & 177 & 54.0 & 43.1 & 砂岩 & $\begin{array}{l}\text { 海砂 } 50 \% \\
\text { 海形 } 50 \%\end{array}$ & $\mathrm{AE}$ \\
\hline 8 & 普通-27-15-25-N & 166 & 51.0 & 40.4 & 陸砂利 & 注砂 & $\mathrm{AE}$ \\
\hline 9 & 普通-27-15-25-N & 183 & 53.0 & 47.3 & $\begin{array}{l}\text { 址岩 70\% } \\
\text { 石戻岩 30\% }\end{array}$ & $\begin{array}{l}\text { 理炭 } 70 \% \\
\text { 陸砂 } 30 \%\end{array}$ & $\mathrm{AE}$ \\
\hline 10 & 音通-24-15-20-N & 169 & 57.5 & 46.8 & 石灰岩 & $\begin{array}{c}\text { 陸砂 } 60 \% \\
\text { 石灰岩 } 40 \%\end{array}$ & $\mathrm{AE}$ \\
\hline 11 & 普通-24-15-20-N & 174 & 56.5 & 43.9 & 石灰岩 & 砂 & $\mathrm{AE}$ \\
\hline 12 & 普通-24-15-20-N & 173 & 57.0 & 45.3 & 硬質的岩 & $\begin{array}{c}\text { 陸砂 } 60 \% \\
\text { 硬質砂岩 } 40 \%\end{array}$ & $\mathrm{AE}$ \\
\hline 13 & 捍通-24-15-20-N & 175 & 58.3 & 46.6 & 石灰岩 & $\begin{array}{l}\text { 珪岩 } 70 \% \\
\text { 陸砂 30\% }\end{array}$ & $\mathrm{AE}$ \\
\hline 14 & 普通-24-15-20-N & 174 & 57.5 & 47.9 & 石灰岩 & $\begin{array}{c}\text { 石灰岩 } 65 \% \\
\text { 山砂 } 35 \%\end{array}$ & $\mathrm{AE}$ \\
\hline
\end{tabular}

* $\mathrm{AE}: \mathrm{AE}$ 減水剂, 高 $\mathrm{AE}$ ：高性能 $\mathrm{AE}$ 減水剂

収縮試験を実施した。コンクリートはレディーミクスト コンクリート工場の試験空において練り混ぜを行い，1

Development of Rapid Drying Shrinkage Evaluation System By H. Momose, T. Kanda, K. Imamoto and H. Mihashi

Concrete Journal, Vol.47, No.10, pp.22 29, Oct. 2009

Synopsis This paper deals with development of rapid drying shrinkage evaluation system which consists of drying shrinkage testing method which enables us to save testing labor, and prediction of drying shrinkage strain of concrete from short-term test. This proposing method was applied to ready-mixed concretes on many construction sites, and robustness and reliability of the method were demonstrated.

Keywords : drying shrinkage, drying shrinkage testing method, prediction, short-term test, ready mixed concrete 
調合につき $100 \times 100 \times 400 \mathrm{~mm}$ の供試体を 3 体ずつ, 埋込みひずみゲージを埋設した $\Phi 100 \times 200 \mathrm{~mm}$ の供試 体を 3 体ずつ作製した。供試体のうち前者をJIS 法に よる測定に，また後者を省力化法による測定に供した。 コンクリート打設直後から $20^{\circ} \mathrm{C}$ 封か九養生とし, 材齢 1 日において脱型し $20^{\circ} \mathrm{C}$ 水中養生とした。材齢 7 日に おいて $20 \pm 3^{\circ} \mathrm{C}, \quad \mathrm{RH} 60 \pm 5 \%$ の恒温恒湿室で気乾養生 を開始するとと屯に，省力化法および JIS 法のひずみ 計測を開始した。

省力化法では, 埋込みひずみゲージを静ひずみ測定器 に接続し乾燥材齢 182 日まで乾燥収縮ひずみの自動計測 を行った。JIS 法では, 乾燥材齢 $0,7,14,28,56,91,182$ 日において，コンパレータにより乾燥収縮ひずみを計測 した。

\section{3 検 討結果}

省力化法と JIS 法の試験結果を図-2 (a)〜 (c) に, 試 験方法が乾燥収縮ひずみ結果に与える影響を図-3およ び図-4 に示す。図中の各試験結果は 3 体の試験結果の 平均值を示している。本実験では, 乾燥材龄 182 日時点 の乾燥収縮ひずみが $500 \mu \sim 1000 \mu$ であり, 非常に広い 範囲に分布する結果となった。また, JIS 法の試験結果 に比べて, 省力化法による試験結果の方が若干大きい傾 向が認められた。試験方法の違いとして, (1)測定位置, (2)試験体形状, (3)測定方法が挙げられる。JIS 法では試
験体表面部を測定しているのに対し，省力化法では試験 体中心部を測定しており, 両試験体の断面積に対する外 気に接する部分の周長が同程度であることから，試験体 表面部を測定している JIS 法の方が大きい值を示すと 考えられるが, 実際には省力化法の方が大きい值を示し ている。この理由として, Wittmann らは, 試験体断 面の相刘湿度分布により試験体表層部の方が乾燥収縮ひ ずみは大きくなるが, 内部拘束により表層部に微細ひび 割れが生じ，見掛け上のひずみは試験体内部に比べて試 験体表層部の方が小さことを示唆している5

省力化法と JIS 法の試験結果には若干の差があるた め, 省力化法による試験を行う場合には省力化法の試験 結果を補正し JIS 法の結果を推定する必要がある。こ の省力化法および JIS 法から得られた試験結果の差異 を補正する係数として，図-4 に示す傾き 0.9465 を省力 化法の乾燥材齢 182 日の試験結果に乗じることにより, JIS 法による乾燥材齢 182 日の試験結果を推定できると 考えられる。

省力化法上 JIS 法の测定結果に関し，標準偏差抢上 び変動係数について算定した結果を図-5に示す。本実 験では全ての調合において 3 体の供試体を作製し実験を 実施しており，図中には各調合についてこれら 3 体の試 験結果の標準偏差および变動係数を算定しその平均值を 示している。図-5 から, JIS 法は乾燥材齢によらず標

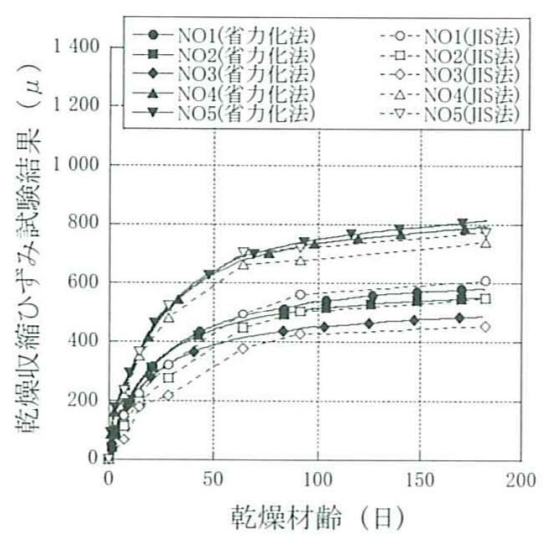

図-2（a）乾燥収縮ひずみ試験結果 (NO.1 5)

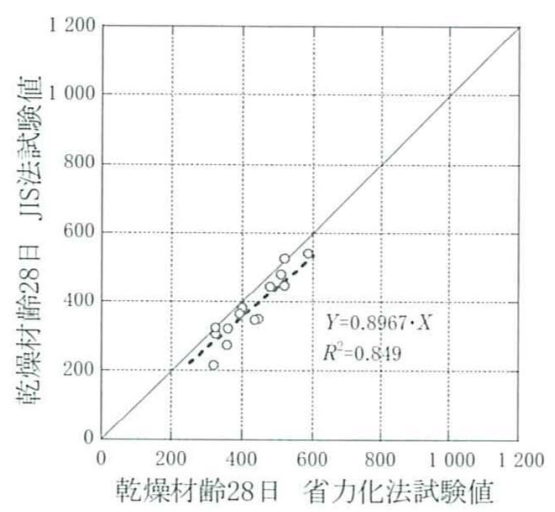

図-3 試験方法が乾燥収縮ひずみに与える 影響（乾燥材齢 28 日）

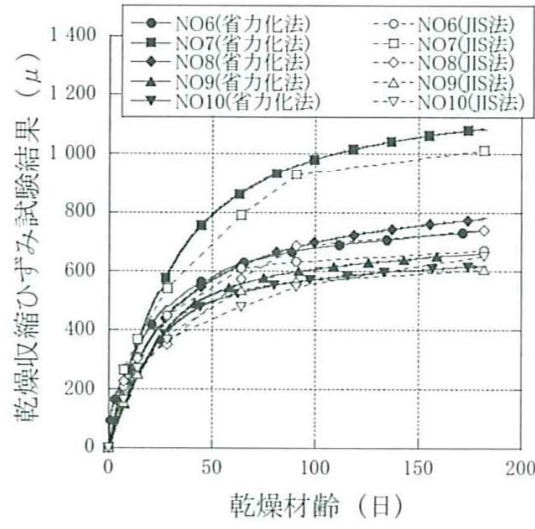

図-2（b）乾燥収縮ひずみ試験結果 (NO.6 10)

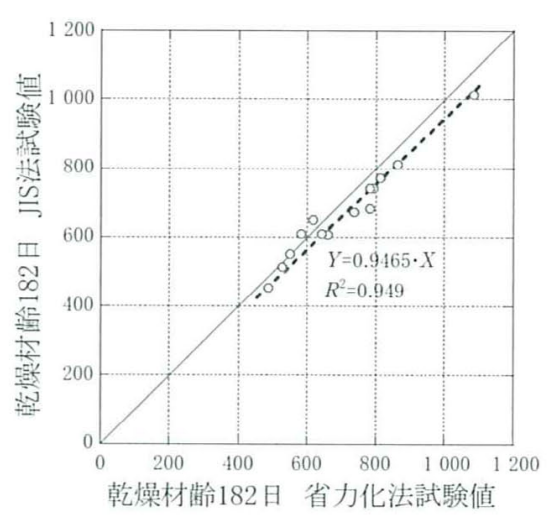

-4 試験方法が乾燥収縮ひずみに与える 影響（乾燥材澮 182 日）

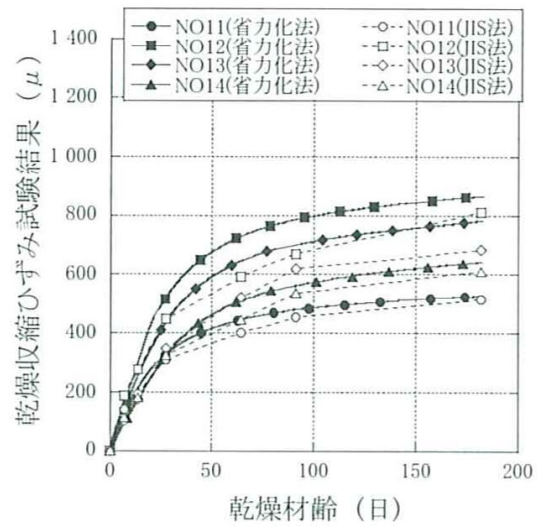

図-2（c）乾燥収縮ひずみ試験結果 (NO.11 14)

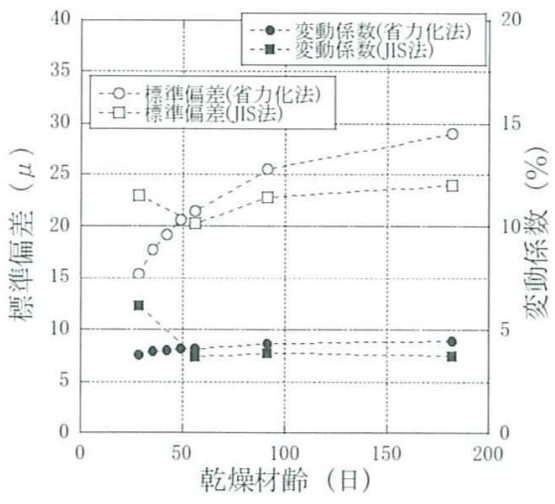

図-5 各試験法の標準偏差および変動係数 
準偏差は同程度であるのに対し，省力化法は乾燥材齢が 大きくなるに従い標準偏差む増大する傾向にあることが 確認できた。また, 試験值の変動係数はJIS 法の乾燥 材齢 28 日における值が若干大きいが，その他の材齢で は試験法および乾燥材齫によらず $4 \%$ 程度の值を示して おり, 省力化法は JIS 法と同程度の試験精度を有して いると判断される。

以上の検討結果から, 省力化法により得られた乾燥材 齢 182 日の試験結果に補正係数 0.9465 を乗じて, コン クリートの乾燥収縮における材料特性值となる乾燥材踰 182 日の JIS 法の值を得ることとした。

4. 外挿法による長期乾燥収縮ひずみの予測

\section{1 外挿法の概要}

省力化法により得られた短期の乾燥収縮ひずみデー夕 から, 乾燥材齢 182 日の乾燥収縮ひずみを予測する手法 として外挿法を提案した ${ }^{6)}$ 。外抻法の模式図を図-6に示 す。外挿法は (1) 式抢よび (2) 式に示す CEB-FIP の 乾燥収縮ひずみ予測式を用いて，以下のステップに基づ いて実施される。

ステップ I : 当該短期データの各乾燥材齢について乾燥 収縮最終值を（1）式から導いた（3) 式に より算定する。

ステップII：各乾燥材齢に対応する算定最終值が何らか の值（予测最終值）に漸近すると仮定して

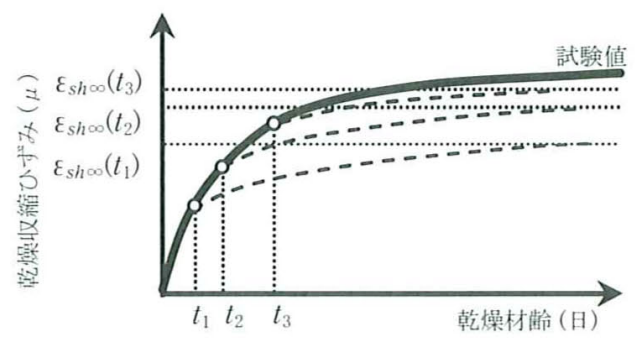

I ) 各乾燥材龄における終局值の予測

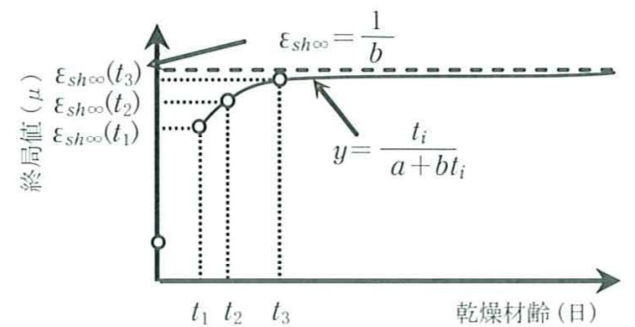

II）乾燥材噛之終局值

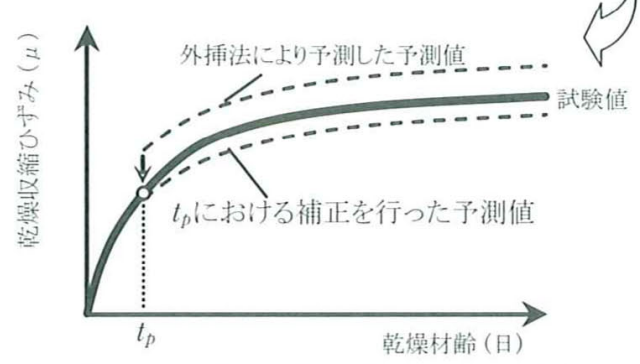

III) 予測材秢 $t_{b}$ 時点の実験值と予測值の差を補正

図-6 外挿法の模式図
両者の関係を図-6 中のステップIIに示す 双曲線により最小自乗近似し予測最終值を 得る。

ステップIII：予測最終值に基づく曲線において予測值と 当該短期データの予測材齢の実測值に生じ た差を（4）式により補正する。ここで乾 燥材齢 $t_{i}$ 日に依存する乾燥収縮ひずみ式 が得られ，乾燥材齢 182 日の乾燥収縮ひず みを推定する。

$$
\begin{aligned}
& \varepsilon_{s h}\left(t_{i}\right)=\varepsilon_{s h \infty \infty} \cdot \beta_{s}\left(t_{i}\right) \\
& \beta_{s}\left(t_{i}\right)=\left[\frac{t_{i}}{0.035 D^{2}+t_{i}}\right]^{0.5} \\
& \varepsilon_{s h \infty}=\varepsilon_{s h}\left(t_{i}\right) / \beta_{s}\left(t_{i}\right) \\
& \beta_{s h}\left(t_{i}\right)=\frac{1}{b} \cdot \beta_{s}\left(t_{i}\right)-\left\{\frac{1}{b} \cdot \beta_{s}\left(t_{p}\right)-\varepsilon_{s h}\left(t_{p}\right)\right\}
\end{aligned}
$$

ここに, $t_{i}$ : 乾燥材齢, 乾燥開始日を基点とした材齢 (日) $=t-t_{0}$

$t$ : 材齢，打設日を基点とした材龄

$t_{0}:$ 乾燥開始材齢 $($ 日 )

$t_{p}$ : 予測材齢，外挿法により予測を実施した乾 燥材齢 (日)

$\varepsilon_{s h}\left(t_{i}\right)$ : 乾燥材龄 $t_{i}$ 日における乾燥収縮ひずみ

$\varepsilon_{s h \infty}\left(t_{i}\right)$ : 乾燥材齢 $t_{i}$ 日において算定した乾燥収縮 ひずみ最終值

$D:$ 部材の仮想厚さ $(\mathrm{mm})=2 A_{0} / u$

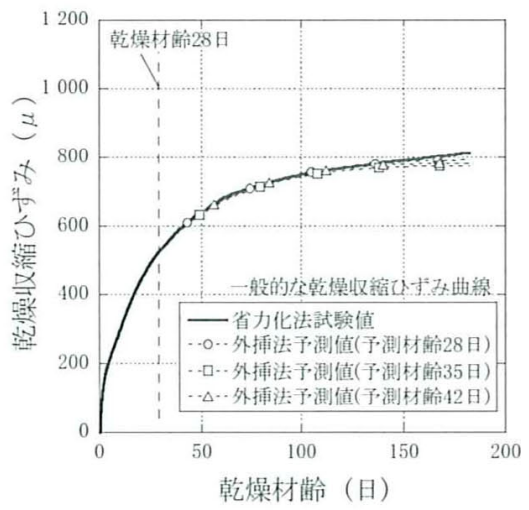

図-7（a）外挿法による予測例（一般的 なひずみ曲線)

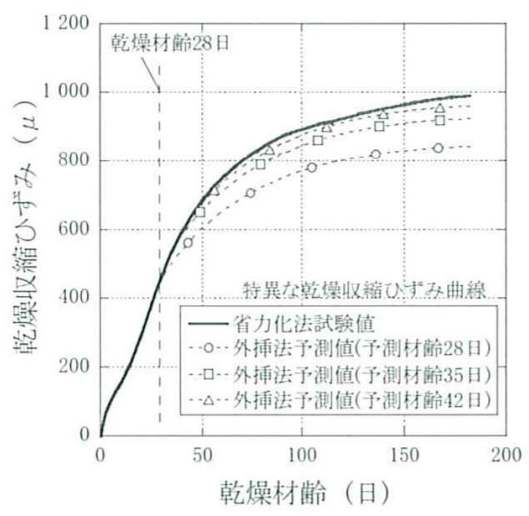

図-7（b）外挿法による予測例（特異な ひずみ曲線) 
$A_{c}:$ 部材の断面積 $\left(\mathrm{mm}^{2}\right)=\pi r^{2}$

$u$ : 外気に接する部分の周長 $(\mathrm{mm})=2 \pi r$

$b:$ 威-6 中のステップ II で算定した乾燥収縮 ひずみ最終值の逆数 $\varepsilon_{s h \omega}=1 / b$

本システムでは, 外抻法による長期乾燥収縮ひずみの 予測精度を向上する心゙く, 乾燥材齡 28 日までの乾燥収 縮ひずみ結果から，特異なひずみ挙動を示すむのについ ては，予測材齢を延長する手法を採用している。

一般的なひずみ曲線の予測例在図-7 (a) に，特異な ひずみ曲線の予測例老図-7（b）に示す。図-7 (a)に示 すように, 一般的なひずみ曲線は, 乾燥開始直後に最も ひずみ勾配が大きく，乾燥材齢の経過に従ってひずみ勾 配が緩やかになる。このような一般的なひずみ曲線であ 扎ば, 図-7 (a) のように, 乾燥材齢 28 日で外挿法によ る予測を実施しても高い精度で長期乾燥収縮ひずみを予 測できる。しかしながら，図-7 (b) に示すように，乾 燥過程でひずみ勾配が急激に大きくなるような特異なひ ずみ曲線を示す場合には，予測材齢が短いと，十分な精 度で長期乾燥収縮ひずみを予測できない結果となる。

上述のように，短期乾燥収縮ひずみのひずみ曲線を確 認して予測材龄の延長老判断する手法は極めて合理的で あり，省力化法のようにひずみデータの連続計測を実施 して初めて採用できる手法である。

\section{2 検 討 概 要}

外挿法による長期乾燥収縮ひずみの予測精度を検証す るべく, 表-3 に示す計 71 調合のコンクリートを対象に, 省力法による乾燥収縮試験を実施し，外挿法による長期 乾燥収縮ひずみの予測を実施した。

本実験では，表-3 に示す計 71 調合のコンクリートに ついて, 省力化法により乾燥材龄 182 日までの乾燥収縮 ひずみを計測し，予测材龄 28, 35, 42 日において外扱法 により乾燥材齢 182 日の乾燥収縮ひずみを予测した。コ ンクリートはレディーミクストコンクリート工場の試験 室において練り混ぜを行い，1調合につき埋込みひずみ ゲージを埋設した $\Phi 100 \times 200 \mathrm{~mm}$ の供試体を 3 体ずつ 作製した。コンクリート打設直後から $20^{\circ} \mathrm{C}$ 封かん養生 とし，材齢 1 日において脱型した彴， $20^{\circ} \mathrm{C}$ 水中養生と

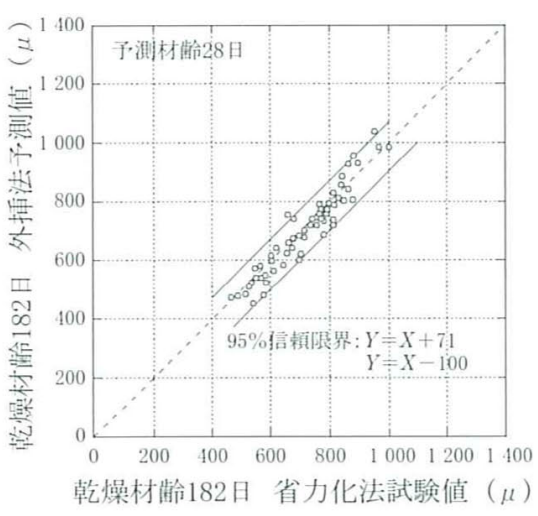

図-8（a）外挿法による予測精度（予測材 龄 28 日）

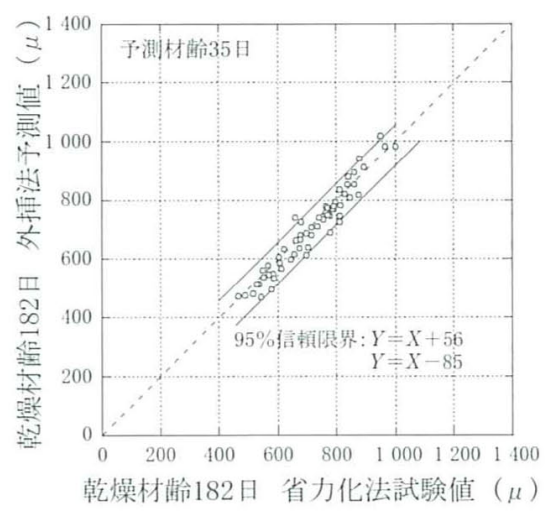

図-8（b） 外挿法による予測精度（予测材 龄 35 日）
表-3 外挿法の検討に供した調合の一覧

\begin{tabular}{|c|c|}
\hline 項目 & 試験䡉囲 \\
\hline 調合の水準 & 71 調台 \\
\hline 呼び强度 & $21 \sim 42$ \\
\hline スランプ $(\mathrm{cm})$ & $12 \sim 18$ \\
\hline 单位水量 $\left(\mathrm{kg} / \mathrm{m}^{3}\right)$ & $166 \sim 190$ \\
\hline 水セメント比 $(\%)$ & $40.1 \sim 63.0$ \\
\hline 紐骨材率 $(\%)$ & $40.4 \sim 54.7$ \\
\hline 笡骨材種類 & $\begin{array}{l}\text { 砂岩单独, 砂単独, 砕不单独 } \\
\text { 石灰岩混合, 列混合, その他 }\end{array}$ \\
\hline 細骨材種類 & $\begin{array}{l}\text { 石灰岩单独, 砂岩単独, 砂利単独 } \\
\text { 石灭岩混合, 砂岩混合, その他 }\end{array}$ \\
\hline 混和剤種類 & $\mathrm{AE}$ 減水剂, 高性能 $\mathrm{AE}$ \\
\hline 地域（工場の所在地） & $\begin{array}{c}\text { 関東, 首都圏, 信越 } \cdot \text { 北陸, } \\
\text { 東海, 近畿, 九州 }\end{array}$ \\
\hline
\end{tabular}

した。試験体運送中の材齢 3〜 5 日の間に供試体が乾燥 しないように配慮しながら，試験機関に運搬しその後 $20^{\circ} \mathrm{C}$ 水中養生とした。

材齡 7 日において $20 \pm 3^{\circ} \mathrm{C}, \quad$ RH $60 \pm 5 \%$ の恒温恒湿 室で気乾養生を開始するとともに，省力化法によるひず み計測を開始した。省力化法では，埋込みひずみゲージ を静ひずみ測定器に接続し乾燥材齢 182 日まで乾燥収縮 ひずみの自動計测を行った。

\section{3 検 討結果}

各予测材齢における外挿法の予測精度を図-8 (a) （c）に示す。図中には，全 71 調合それぞれにおいて乾 燥材龄 182 日における外挿法による予測值と乾燥材龄 182 日における省力化法試騃值の差を算定し, その差の ばらつきから $95 \%$ 信頼限界を算定することで, 予測精 度の指標とした。

戍-8（a）から，予測材龄 28 日における 95\% 信頼限 界は土100 $\mu$ 以下であり，外插法により高い精度で長期 乾燥収縮ひずみを予測できていると考えられる。また， 図-8 (a)〜 (c) から，予測材龄が長くなるに徉い，95\% 信頼限界は減少していることが確認できる。乾燥収縮ひ ずみの品質評価を実施する際に，評価に要する時間に余 裕がある場合には，予測材路を延辰することで予測精度 の向上が図れると考えられる。

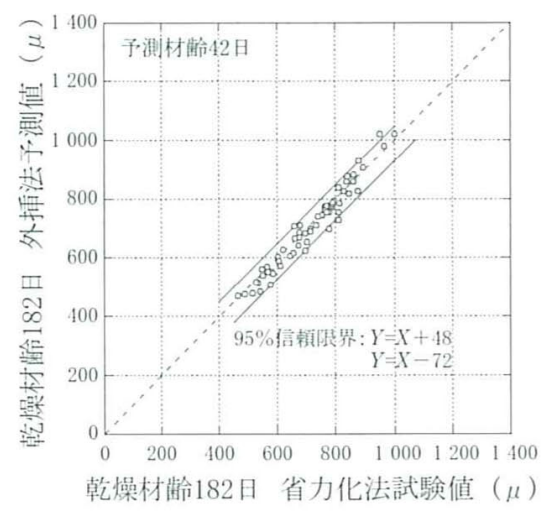

図-8（c）外挿法による予測精度（予测材 齢 42 日) 
表-4 実適用に供した調合の一覧

\begin{tabular}{|c|c|}
\hline 項目 & 試騃範囲 \\
\hline 調合の水準 & 280 調合* \\
\hline 適用物件数 & 79 現場 \\
\hline 呼び強度 & $21 \sim 42$ \\
\hline スランブ $(\mathrm{cm})$ & $8 \sim 21$ \\
\hline 単位水量 $\left(\mathrm{kg} / \mathrm{m}^{3}\right)$ & $148 \sim 190$ \\
\hline 水セメント比 (\%) & $38.9 \sim 64.0$ \\
\hline 細骨材率（\%） & $37.7 \sim 54.7$ \\
\hline 粗骨材種頑 & $\begin{array}{l}\text { 所岩単独, 砂単独, 砕石単独 } \\
\text { 石岩混合, 砂混合, その他 }\end{array}$ \\
\hline 細骨材種類 & $\begin{array}{l}\text { 石灰岩单独, 砂岩単独, 砂利単独 } \\
\text { 石灰岩混合, 砂岩混合, その他 }\end{array}$ \\
\hline 混和剂種類 & $\mathrm{AE}$ 減水剂, 高珄能 $\mathrm{AE}$ \\
\hline 地域（レミコン工場の所在地） & $\begin{array}{l}\text { 東北, 関東, 首都圈, 信越 - 北陸, } \\
\text { 東海, 近畿, 中国, 四国, 九州 }\end{array}$ \\
\hline
\end{tabular}

*280 調合には表-3の 71 調合を含む

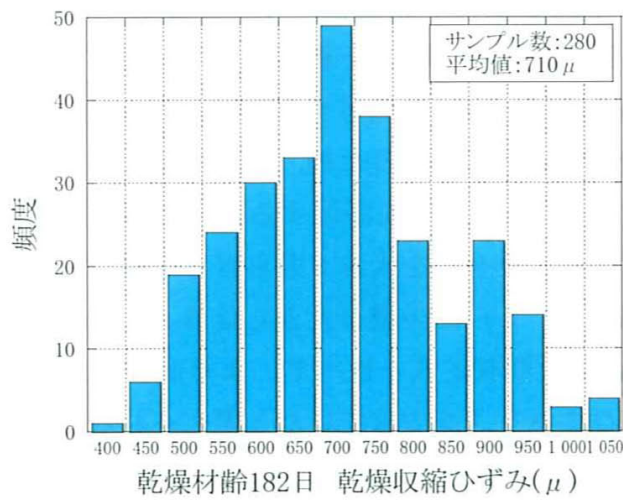

図-9 乾燥収縮迅速評価システムの適用実績

5. 適用実績および予測精度の検証

\section{1 適用実績の概要}

本システムは，これまでに表-4 に示す計 280 調合の コンクリートに適用した試験実績があり，79 件の実工 事に適用さ机ている。図-9 は，表-4に示す 280 調合の コンクリートの試験結果を示している。図中の乾燥収縮 ひずみは, 省力化法により乾燥材齢 182 日まで継続して 測定し，その試験結果に補正係数 0.9465 を乘じて得ら れた乾燥材齢 182 日の JIS 法の結果に相当する值で ある。

図-9 から，280 調合のコンクリートの乾燥収縮ひずみ は，その平均值が $710 \mu$ であり，400 1050 $\mu$ 之非常に 広く分布している結果となった。このことから, 乾燥収 縮によるひび割机を対象とした精度の高い制御設計を実 施する上で，実際に使用するコンクリートの乾燥収縮ひ ずみを把握することが重要であることが分かる。

粗骨材種類が乾燥収縮ひずみに与える影響を図-10に 示す。図-10は，280調合のコンクリートを表-5 の項目 に従い整理した図である。図-10から，石灰岩単独の場 合の平均值は $587 \mu$, 砂岩単独の場合の平均値は $832 \mu$ であった。各骨材の平均值で比較す机ば，全体の平均值

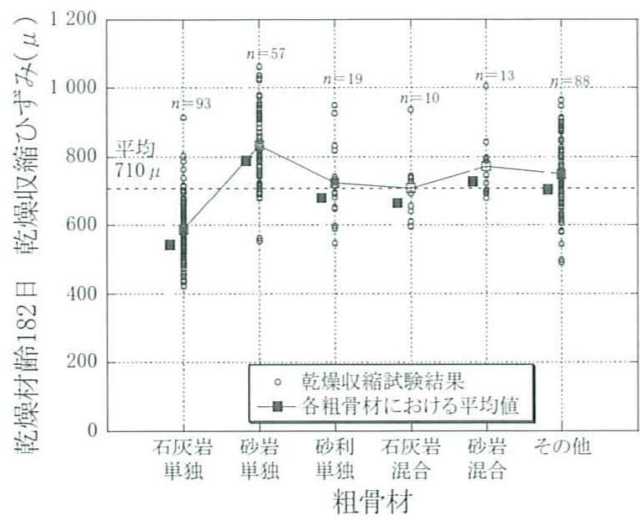

図-10 粗骨材種類が乾燥収縮ひずみに与える影響

表-5 粗骨材種類の分類

\begin{tabular}{|c|c|c|}
\hline 項目 & 分類分け & 詳細 \\
\hline \multirow{6}{*}{ 祖骨材 } & 石灰岩笚独 & 粗骨材に石灰岩を $100 \%$ 使用 \\
\hline & 砂岩䇲独 & 粗骨材に砂岩·硬質砂岩を $100 \%$ 使用 \\
\hline & 砂利単独 & 粗骨材に的利を $100 \%$ 使用 \\
\hline & 石灰岩混合 & 粗骨材に石灰岩を $50 \%$ 以上使用 \\
\hline & 砂岩混合 & 粗骨材に砂岩・硬質砂岩を $50 \%$ 以上使用 \\
\hline & その他 & 上記以外 \\
\hline
\end{tabular}

である $710 \mu$ に対して，石灰岩単独は $-123 \mu$ ，砂岩単 独は+122 $\mu$ であり，石灰岩を用いたコンクリートは乾 燥収縮がさく，砂岩を用いたコンクリートは乾燥収縮 が大きい結果となった。この傾向はこれまでの研究にお ける傾向之同じであるり。しかしながら，乾燥収縮ひず みの大きい石灰岩単独の場合や乾燥収縮ひずみの小さい 仯岩単独の場合むあることから，同じ分類の骨材で屯乾 燥収縮ひずみの差は大きいことが分かる。したがって, 岩種による乾燥収縮ひずみの判定は，元の傾向を概ね椎 測できる程度であり，そのことだけで断定することはり スクを伴うと考えら机る。このことからあ，本システム の上うに，実際に使用するコンクリート走用いた試験に より，そのコンクリートの乾燥収縮を評価することは極 めて重要であるといえる。

\section{2 外挿法による予測精度の検証}

表-4 および図-9 に示す計 280 調合のコンクリートを 対象に，外挿法による長期乾燥収縮ひずみの予測精度を 検証した。外抻法による予測精度老図-11に示す。外挿 法による長期乾燥収縮ひずみの予測は, 予測材齿 28 日 を標準とし，乾燥材踰 28 日までの乾燥収縮ひずみ挙動 に特異なひずみ曲線が認められた場合には，収縮挙動が 比較的安定した之判断される材齢まで予測材齢老延長し た。また，図中には図-8 (a)〜 (c) 上同様に，95\% 信頼 限界走している。図-11 から，95\% 信頼限界は $\pm 100 \mu$ 程度以下であり，多くの実物件に適用した事例 においても，外挿法により高い精度で長期乾燥収縮ひず みを予测できていたと考えられる。

09 年 2 月に改正さ扎た JASS 5 では, 簡易な早期判 


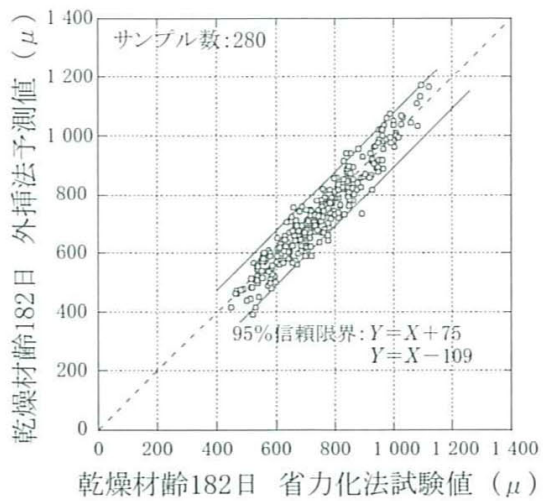

図-11 外挿法による予測精度

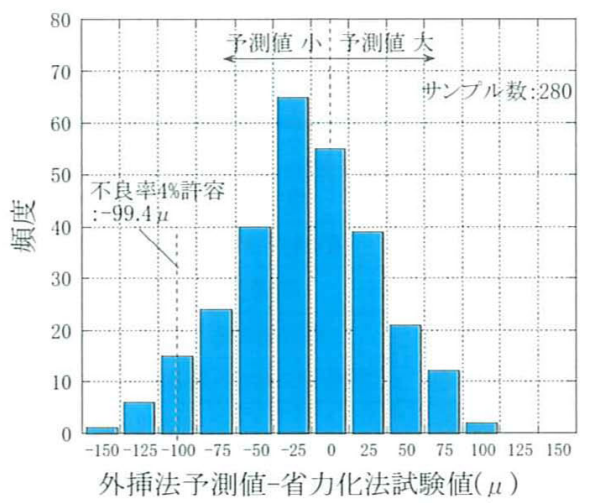

図-12 外挿法による予測誤差

定式（以下，AIJ 早期判定式）を提案しているリ。のの 手法は, JIS 法による乾燥材齢 28 日の乾燥収縮ひずみ 試験值に, 不良率 $4 \%$ 老許容した安全側の係数として 2.11 を乗じることで, 乾燥材澮 182 日の乾燥収縮ひず みを予測するむのであり，予測精度は低いむのの簡便で あることから実用性の高い手法であるといえる。この AIJ 早期判定式に做い，外捜法においても不良率 $4 \%$ を許容した安全率を設定する場合, 図-12に示すように, 外插法予測值に $100 \mu$ を加算することで, 安全側の評価 が可能になると考えられる。

安全率老見込んだ各予測手法の予測精度を図-13に示 す。図中の試験值とは, 省力化法により得られた乾燥材 龄 182 日の省力化法試験值に, 補正係数 0.9465 を乗じ て得られた乾燥材齢 182 日の JIS 法の值である。図中 の外挿法による予測值とは, 省力化法による短期試験デー 夕から外挿法により乾燥材粭 182 日の外挿法予測值を推 定し，不良率 $4 \%$ を許容した安全側の值として $100 \mu$ を 加算し, 更に補正係数 0.9465 を乗じて得られた乾燥材 齢 182 日の JIS 法の予测值である。また, 図中の AIJ 早期判定式に上る予測值とは, 省力化法により得られた 乾燥材啮 28 日の省力化法試験值に, 試験法の誤差を補 正するため, 図-3 に示す係数 0.8967 を乗じ, 不良率 $4 \%$ を許容した安全側の係数として 2.11 を乗じた值で ある”。

図-13 は, 乾燥収縮ひずみの一般的な目標値として挙 げられる $800 \mu$ を基準に, 安全率を見込んだ各予測手法

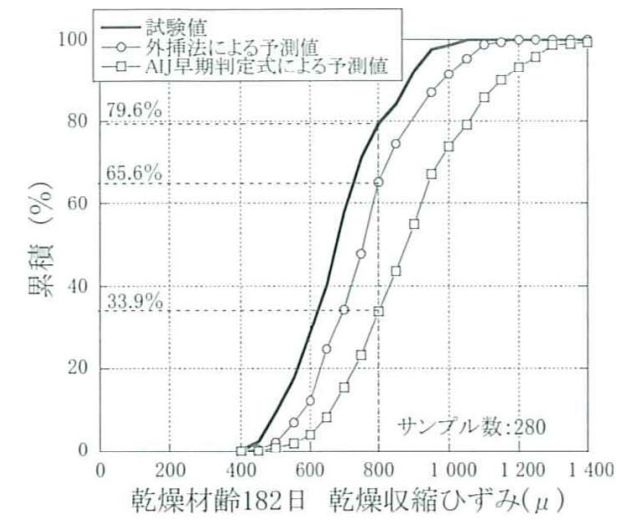

図-13 安全率を見込んだ各予測手法の予測精度

の予測精度を示した図である。全 280 調合の試験結果中, 全体の $79.6 \%$ は $800 \mu$ 以下を満足していることが確認 できる。これらのコンクリートに対して，安全率を見込 んだ各予測手法の予測值は, AIJ 早期判定式では全体 の $33.9 \%$ が $800 \mu$ 以下を満足し, 外挿法では全体の $65.6 \%$ が $800 \mu$ 以下を満足する結果となった。各予測值 は安全率を見込んでいるため, 当然のことながら, 試験 值に比へてて $800 \mu$ 以下を満足する割合は減少するが，予 測精度が悪く安全率を大きく取らざるを得ない手法を用 いた場合は, この減少量が大きくなる。すなわち，外挿 法は AIJ 早期判定式と比べて, 上り高い精度で長期乾 燥収縮ひずみを予測できていたと考えられる。

\section{3 乾燥収縮迅速評価システムによる適用事例}

本システムを実物件に適用した事例を図-14に示す。 本物件の出荷予定工場は 2 工場であったため，それぞれ の工場において試し練りを実施し，本システムによる乾 燥収縮試験老実施した。図-14 から，A工場の乾燥収縮 は $560 \mu, \mathrm{B}$ 工場の乾燥収縮は $846 \mu$ であり, 工場間の 乾燥収縮の差は $300 \mu$ 程度であった。図-14 から，A工 場のコンクリートの乾燥収縮は一般的なコンクリートと 比べて非常に小さく，B工場のコンクリートの乾燥収縮 は若干大きいことがわかる。本物件では，収縮ひび割れ が懸念される地上躯体に乾燥収縮が小さい A 工場のコ ンクリートを用い，収縮ひび割れが大きな問題とならな い地下躯体に乾燥収縮の大きな B 工場のコンクリート

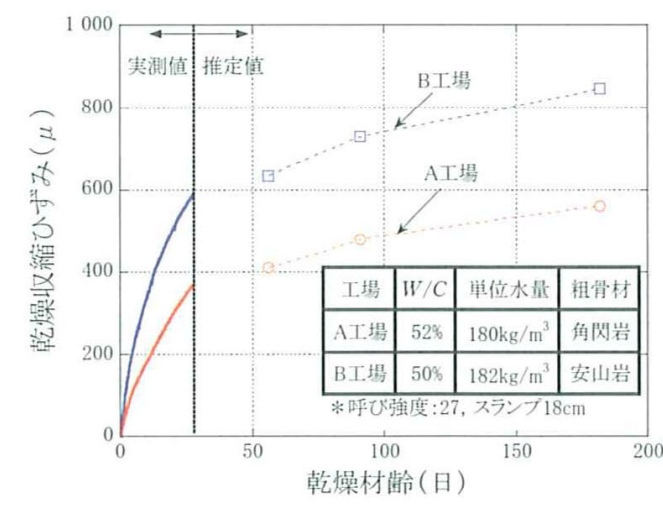

図-14 乾燥収縮迅速評価システムの実施例 
を使用した。乾燥収縮を把握することは, 精度の高い制 御設計に寄与するだけでなく，本物件のように合理的な ひび割れ対策も実現できる。

\section{4 乾燥収縮迅速評価システムの有効活用}

本システムを調合検討に有効活用した事例を紹介する。 図-10に示したように，石灰岩砕石による粗骨材を用い ることで乾燥収縮ひずみの低減が期待できることが明ら かとなったが，現状では石灰岩砕石がコンクリート用骨

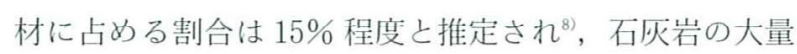
供給が難しい立地条件にあるレディーミクストコンクリー 卜工場屯多く存在することから, 乾燥収縮を低減すると いう目的から石灰岩粗骨材の利用を促進させることには 様々な問題があると考えられる。本事例は, そのような 立地条件にあるレディーミクストコンクリートの調合検 討として, 乾燥収縮の抑制を目的とした骨材の混合利用 の検討を実施した。

粗骨材混合実験の概要を表-6 に示す。実験では, 砂 岩砕石之石灰岩砕石の 2 種類の砕石粗骨材を用い, その

表-6 粗骨材混合実験の概要

\begin{tabular}{|c|c|c|c|c|c|c|c|}
\hline \multirow[b]{2}{*}{$\begin{array}{c}\text { 調合の } \\
\text { 種類 }\end{array}$} & \multicolumn{3}{|c|}{ 調合条件 } & \multicolumn{4}{|c|}{ 実験結果 } \\
\hline & $\begin{array}{c}\text { 砂岩 } \\
\text { 粗骨材の } \\
\text { 混合率 } \\
(\%)\end{array}$ & $\begin{array}{c}\text { 石灭岩 } \\
\text { 粗骨材の } \\
\text { 混合率 } \\
(\%)\end{array}$ & $\begin{array}{l}s / a \\
(\%)\end{array}$ & $\begin{array}{c}\text { スランプ } \\
(\mathrm{cm})\end{array}$ & $\begin{array}{c}\text { 空気量 } \\
(\%)\end{array}$ & $\begin{array}{c}\text { 標準欴生 } \\
28 \text { 日 } \\
\text { 压㴼強度 } \\
\left(\mathrm{N} / \mathrm{mm}^{2}\right)\end{array}$ & $\begin{array}{c}\text { 乾燥収樎 } \\
\text { ひずみ } \\
(\mu)\end{array}$ \\
\hline S 100 & 100 & 0 & 50.5 & 19.0 & 4.5 & 37.8 & 936 \\
\hline S 75 & 75 & 25 & 50.7 & 19.5 & 4.5 & 38.4 & 842 \\
\hline S 50 & 50 & 50 & 50.7 & 20.0 & 4. 4 & 38.9 & 851 \\
\hline S 25 & 25 & 75 & 50.8 & 19.5 & 4.5 & 38.3 & 736 \\
\hline S 0 & 0 & 100 & 51.0 & 20.0 & 4. 2 & 39.8 & 696 \\
\hline
\end{tabular}

$* W / C: 55 \%, W: 175 \mathrm{~kg} / \mathrm{m}^{3}$

\section{表-7 粗骨材の物性}

\begin{tabular}{c|c|c}
\hline 粗骨材の品質 & 刑岩粗骨材 & 石灰岩粗骨材 \\
\hline \hline 絶乾密度 $\left(\mathrm{g} / \mathrm{cm}^{3}\right)$ & 2.63 & 2.70 \\
\hline 吸水率 $(\%)$ & 1.14 & 0.33 \\
\hline 実積率 $(\%)$ & 60.6 & 59.5 \\
\hline 粗粒率 $(\%)$ & 6.65 & 6.61 \\
\hline
\end{tabular}

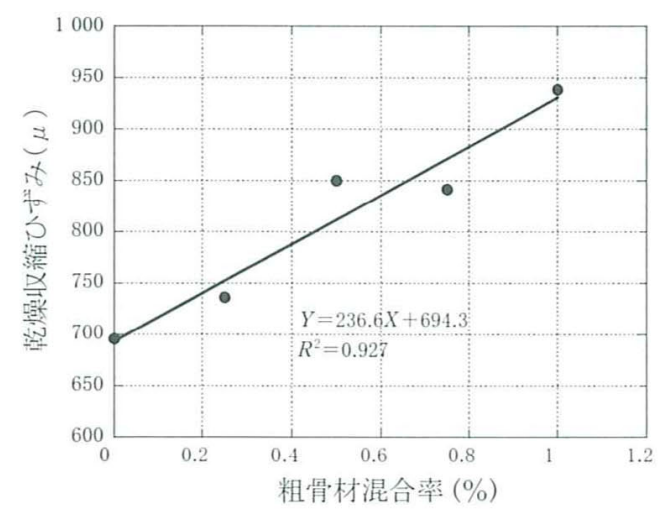

図-15 粗骨材混合実験の結果
混合比率を变化させて 5 種類のコンクリートを調合した。 これらの 5 調合を対象に本システムを適用し，得られた 乾燥収縮ひずみを比較した。砂岩粗骨材と石灰岩粗骨材 の物性は表-7に示すとおりである。

粗骨材混合実験の結果を図-15 亿示す。砂岩粗骨材 100\%のS 100 は $936 \mu$, 石灭岩粗骨材 100\%の S 0 は $696 \mu$ と $240 \mu$ 程度の差があることがわかる。また, 図一 15 より, 乾燥収縮ひずみは, 砂岩粗骨材の混合率に対 して直線的に増加しているとみなせることがわかる。す なわち，2 種類の粗骨材を混合使用したコンクリートの 乾燥収縮ひずみは，それぞれの粗骨材単味によるコンク リートの乾燥収縮ひずみを結ぶ直線上に，混合率に応じ て位置しておうり, 容易に予測が可能と考えられる。本事 例では, 今回の結果を受け，所要の乾燥収縮ひずみを満 足する調合設計を行うに至った。

\section{6.おおりに}

本報では，試験精度を損なうことなく省力化を実現で きる『省力化乾燥収縮試験法』と，4週間の乾燥収縮ひ ずみデータから乾燥材齢 182 日の乾燥収縮ひずみを予測 できる『外插法』から構成される乾燥収縮迅速評価シス テムについて述べ, 本システムを 79 物件, 計 280 調合 のコンクリートに適用した事例について報告した。本シ ステムは，非常に多くの実物件に適用されており，その 長期ひずみの予測精度も高く，高い実用性を有した技術 であることが証明された。JASS 5 の改訂など、コンク リートの乾燥収縮に対する要求は今後も高くなっていく ことが予想されるなか, 高品質の RC 造建築構造物を工 ンドユーザーに提供するための技術の一つとして, 本シ ステムを活用していく予定である。

\section{参 考 文 献}

1）日本建築学会：建築工事標準仕样書・同解説 JASS 5, 2009.2

2）日本建築学会：鉄筋コンクリート造建築物の収縮ひび割れ制御設 計・施工指針 (案) ・ 同解説, 2006.2

3）吉兼 亨：コンクリートの乾燥収㦥 生コンクリートにおける乾 燥収縮の全国実態調查の報告および乾燥収縮の規定への対応につ いて,コンクリートテクノ, Vol.28, No.2, pp.9〜15, 2009.2

4）䦥田徹志・百瀬晴基・今本啓一・三橋博三 : 乾燥収縮試験法の省 力化に関する奏験研究, 日本建築学会構造系論文集, Vol.73, No.628, pp.851 857, 2008.6

5) Giovanni Martinola, Hamid Sadouki, Folker H. Wittmann : Numerical Model For Minimizing Risk of Damage in Repair System, Journal of Materials in Civil Engineering, Vol.13, No.2, 2001. 3-4

6）今本啓一・石井寿美江・閑田徽志・百攧晴基・藤森啓祐：短期デー 夕に基づくコンクリートの乾燥収縮ひずみ予測に関する研究, 日 本建筑学会構造系論文集, No.602, pp.15 20, 2006.4

7）閑田徹志・百瀬晴基・今本敌一・三橋博三：レディーミクストコ ンクリートを対象とした乾嬠収繀の調查研究およびもの統計分析, 日本建筑学会構造系論文集, Vol.73, No.629, pp.1019～1026, 2008. 7

8）コンクリート工学協会：骨材の品質と有効利用に関する研究委員 会報告書, 2007 